\title{
Evaluation of Chromosome Microarray Analysis in a Large Cohort of Females with Autism Spectrum Disorders: A Single Center Italian Study
}

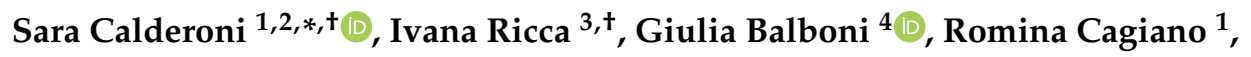 \\ Denise Cassandrini ${ }^{3}$, Stefano Doccini ${ }^{3}{ }^{\oplus}$, Angela Cosenza ${ }^{1}$, Deborah Tolomeo ${ }^{3,5}$, \\ Raffaella Tancredi ${ }^{1}$, Filippo Maria Santorelli ${ }^{3}$ and Filippo Muratori ${ }^{1,2}$ \\ 1 Department of Developmental Neuroscience, IRCCS Fondazione Stella Maris, Viale del Tirreno 331, \\ Calambrone, 56128 Pisa, Italy; romina.cagiano@fsm.unipi.it (R.C.); angela.cosenza@fsm.unipi.it (A.C.); \\ r.tancredi@fsm.unipi.it (R.T.); f.muratori@fsm.unipi.it (F.M.) \\ 2 Department of Clinical and Experimental Medicine, University of Pisa, Via Savi, 10, 56126 Pisa, Italy \\ 3 Molecular Medicine, IRCCS Fondazione Stella Maris, via dei Giacinti 2, Calambrone, 56128 Pisa, Italy; \\ ivana.ricca@fsm.unipi.it (I.R.); d.cassandrini@fsm.unipi.it (D.C.); s.doccini@fsm.unipi.it (S.D.); \\ d.tolomeo@fsm.unipi.it (D.T.); f.santorelli@fsm.unipi.it (F.M.S.) \\ 4 Department of Philosophy, Social and Human Sciences and Education, University of Perugia, \\ Piazza G. Ermini 1, 06123 Perugia, Italy; giulia.balboni@unipg.it \\ 5 Department of Neurosciences, Psychology, Drug Research and Child Health (NEUROFARBA), \\ University of Florence, Viale Pieraccini, 6-50139 Florence, Italy \\ * Correspondence: sara.calderoni@fsm.unipi.it; Tel.: +39-050-886-200; Fax: +39-050-886-273 \\ + These authors contributed equally to this work.
}

Received: 7 September 2020; Accepted: 21 September 2020; Published: 9 October 2020

\begin{abstract}
Autism spectrum disorders (ASD) encompass a heterogeneous group of neurodevelopmental disorders resulting from the complex interaction between genetic and environmental factors. Thanks to the chromosome microarray analysis (CMA) in clinical practice, the accurate identification and characterization of submicroscopic deletions/duplications (copy number variants, CNVs) associated with ASD was made possible. However, the widely acknowledged excess of males on the autism spectrum reflects on a paucity of CMA studies specifically focused on females with ASD (f-ASD). In this framework, we aim to evaluate the frequency of causative CNVs in a single-center cohort of idiopathic f-ASD. Among the $90 \mathrm{f}-\mathrm{ASD}$ analyzed, we found 20 patients with one or two potentially pathogenic $\mathrm{CNVs}$, including those previously associated with ASD (located at 16p13.2 16p11.2, 15q11.2, and $22 q 11.21$ regions). An exploratory genotype/phenotype analysis revealed that the f-ASD with causative CNVs had statistically significantly lower restrictive and repetitive behaviors than those without CNVs or with non-causative CNVs. Future work should focus on further understanding of f-ASD genetic underpinnings, taking advantage of next-generation sequencing technologies, with the ultimate goal of contributing to precision medicine in ASD.
\end{abstract}

Keywords: autism spectrum disorders; copy number variants; females; Array-Comparative Genomic Hybridization (Array-CGH)

\section{Introduction}

Autism spectrum disorders (ASD) are a heterogeneous group of neurodevelopmental pathologies characterized by early onset abnormalities in social communication and interaction, as well as atypically restricted and repetitive behaviors and interests [1]. Despite the exact pathogenesis of idiopathic ASD not yet being fully elucidated, recent evidences suggest an interaction between 
genetic liability and environmental influences in producing early alteration of brain development [2]. In particular, among environmental risk factors, several maternal factors (including age $\geq 35$ years, chronic hypertension, preeclampsia, gestational hypertension, and overweight before or during pregnancy) were associated with ASD in an updated review of the literature [3]. Updated data on the prevalence of ASD in the US (Centers for Disease Control and Prevention, CDC [4]) identified 1 in 54 children as having ASD, while the estimated prevalence of ASD in Italian population is 1 in 87, according to a recent investigation [5].

Crucially, since the first descriptions of autism [6,7], a strong male bias in ASD prevalence has been consistently observed, which becomes even more pronounced in individuals without intellectual disability, according to data from the 80s [8,9]. More recent studies have challenged this assertion, suggesting that missed or wrong diagnoses of ASD females, especially of those with good intellectual and language abilities, contribute to the skewed sex ratio in ASD [10].

The exact mechanisms underlying male vulnerability or female protection in ASD remain complex and scarcely investigated. A multifactorial model has been proposed where a mixture of gene variants and environmental factors contribute to liability, possibly interacting with sex-specific pathways such as those related to hormones or immune function [11,12].

Genetic investigations in ASD revealed frequently sexually dimorphic results. For example, a greater number of de novo copy number variants (CNVs) [13-16] as well as a higher rate of de novo single nucleotide variants (SNVs) found in exome sequences $[17,18]$ have been observed in females with ASD (f-ASD) than in male cases, especially non-sense and splice site $[19,20]$. Conversely, a more recent study pointed to sex-specific mutations, specifically on the $\mathrm{X}$ chromosome, that may contribute to male prevalence in ASD [21]. On the other hand, as far as sex differences in symptom profiles are concerned, some previous studies suggested different phenotypic features in females than in males with ASD [22] like lower IQ [23], more impaired social and/or communicative functioning [24], psychopathological problems [25] and milder restricted and repetitive behaviors [26-28]. However, this issue remains controversial [29-33]. Females with ASD displayed also a higher rate of co-occurring neurological conditions than ASD males, i.e., microcephaly, developmental regression in socialization, minor neurological and musculoskeletal deficits [34], and epilepsy [35], all pointing to sex differences in genetic backgrounds.

The advent of chromosome microarray analysis (CMA) in clinical practice [36] allows for fast detection and accurate characterization of submicroscopic deletions and duplications (CNVs) of genomic DNA associated with ASD [37,38]. Learning societies and ASD experts recommend CMA as part of the first-line evaluation for individuals with ASD [39-41]. However, CMA brings up a higher level of polymorphic genomic rearrangements and the process to attribute causality in complex conditions such as ASD is not easy and straightforward.

This study aims to investigate the frequency of causative CNVs in a single-center cross-sectional idiopathic f-ASD cohort to delineate possible genotype/phenotype associations.

\section{Methods}

We collected the clinical data of a group of 93 females referred consecutively to the Autism Spectrum Disorders Unit of our Children Neuropsychiatry Hospital between 2015 and 2016. The age at the last clinical evaluation ranged from 21 months to 17 years. All participants received a clinical diagnosis of ASD based on the criteria of the Diagnostic and Statistical Manual of Mental Disorders (DSM-5) [1]. All the patients were unrelated.

According to our ASD-screening protocol, neurometabolic conditions and hypoxic-ischemic injury were investigated. All participants were evaluated by an expert clinical geneticist in order to exclude recognizable monogenic syndromes. Prior to this study, each individual had also been tested for the expanded repeat sequences in $5^{\prime}$-UTR of the FMR1 gene as previously reported [42].

Based on this screening, we excluded two females with a history of perinatal hypoxia and diffuse white matter disease detected on brain magnetic resonance imaging (MRI), and one patient with 
macrocephaly harboring a pathogenic mutation in PTEN. In a single case (patient P11) we analyzed CNVs in spite of her presentation of a low-level somatic mosaicism for a fully-mutated/pre-mutated FMR1 allele, because the patient's phenotype could not be fully explained by this genetic condition.

Hence, we tested 90 ASD female individuals for CNVs. Participants were classified as clinically affected by "essential" autism, based on the absence of major congenital abnormalities and major dysmorphism [43,44].

Cognitive evaluation was performed in 87 participants with specific cognitive scales based on the age and the language level. According to the age, children were tested respectively with the Griffiths Mental Development Scale-Revised (GMDS-R) [45], Wechsler Preschool and Primary Scale of Intelligence-third edition (WPPSI, III) [46] or Wechsler Intelligence Scale for ChildrenIV (WISC, IV) [47]. The evaluation of non-verbal females was performed using the Leiter International Performance Scale-Revised (Leiter-R) [48]. In three participants, the cognitive assessment was not performed because of scarce compliance due to severe autism symptoms.

Clinical assessment of expressive language skills defined females with a complete absence of language $(n=27)$ and a group of "verbal" f-ASD $(n=63)$.

The semi-structured Autism Diagnostic Observation Schedule second edition (ADOS-2) evaluation [49], which provides a measure of autism severity, was available in 67 participants. We recorded the score on the Social Affect (SA) and the Restricted and Repetitive Behaviors (RRB) domains for each proband. Since we used different ADOS modules according to the non-echolalic expressive language level of each patient at the time of the evaluation, we converted the global ADOS scores and the sub-scores of the SA and RRB domains in the corresponding Calibrated Severity Score (CSS) [50,51].

This study was approved by the Pediatric Ethic Committee of Tuscany Region (Italy), and was performed according to the Declaration of Helsinki and its later amendments or comparable ethical standards. All parents or legal representatives signed an informed consent form before the inclusion of their child in the study. The identities of all individuals were omitted.

\section{Procedure}

\subsection{Genetic Analysis}

CMA analyses were performed using the Agilent $8 \times 60 \mathrm{~K}$ Microarray oligonucleotide platform with a median resolution of $100 \mathrm{Kbp}$, according to the manufacture's protocol (Agilent Technologies, Santa Clara, CA, USA). CNV coordinates refer to the Genome Reference Consortium Human Build 37 (GRCh37/hg19).

In each proband, CNVs were confirmed by quantitative polymerase chain reaction (qPCR). Segregation analyses in parental DNA (whenever available) were performed by qPCR. Polymorphic CNVs, based on Database of Genomic Variants data (DGV) [52]), were filtered out.

Non-polymorphic CNVs were classified as "causative" (C-CNVs) or "non-causative" (N-CNVs) according to the American College of Medical Genetics and Genomics (ACMG) guidelines [53]. We considered as "causative": (i) CNVs encompassing genomic regions or genes associated with ASD or with other neuropsychiatric conditions (i.e., intellectual disability, epilepsy and schizophrenia) in the Online Mendelian Inheritance in Man (OMIM) database [54]; (ii) CNVs containing "high confidence" ASD-genes reported in the Simons Foundation Autism Research Initiative (SFARI) Gene database [55] with a score $<3$ or in the Autism Knowledge Base version 2.0 (Autism KB 2.0) database [56] with a score > 16; (iii) CNVs involving "candidate-genes" for ASD either reported in association with autism in literature, or listed in the aforementioned databases and with a SFARI Gene score $\geq 3$ or an Autism $\mathrm{KB}$ score $\leq 16$ (suggestive or "low confidence" candidate-genes). Conversely, CNVs were considered non-causative (N-CNVs) if they have never been associated with ASD or other neurodevelopmental disorders (NDDs). Patients who tested negative for CNVs were classified as "without CNVs" (w-CNVs). 
To recognize significantly enriched functional modules, ASD-candidate genes encompassed by C-CNVs were evaluated by bioinformatics tools. A Core analysis run in the Variant Effects Analysis mode through the use of the Ingenuity Pathway Analysis (IPA) software [57] figured out cellular processes related to our gene dataset (21 genes). A functional network encompassing our ASD-candidate genes was generated. Bridging nodes were denoted evaluating both direct and indirect interactions with stringent level of confidence and only related to neurological diseases. Gene ontology (GO) categorization was carried out using ToppGene Suite [58]. The top three ontologies for Molecular Functions and Cellular Component were annotated and statistical significance of GO terms was reported as - $\log 10$ ( $p$-value).

\subsection{Statistical Analyses}

We used a chi-square test to investigate the association between the CNVs subtype and the type of CNVs (duplication or deletion) and the pattern of inheritance (de novo or inherited, paternal or maternal). A Mann-Whitney test was used to verify if there were any differences in the CNVs burden of the different $\mathrm{CNVs}$ subtypes (excluding patient P23 who carried a whole X-chromosome duplication).

We also investigated the phenotype of the individuals with the different CNVs subtypes testing with the chi-square test the association between the CNVs subtype and cognitive (IQ $\leq 70$ vs. $>70$ ) and language (non-verbal vs. verbal) levels. A Mann-Whitney test was used to ascertain that the groups with different $\mathrm{CNVs}$ subtype were matched on age and to verify if there were any differences in the CCS score obtained on the total ADOS and on its AS and RRB domains. In case of statistically significantly differences we compute for $r$ score as effect size index. This was interpreted as negligible $(r<0.10)$, small $(0.10 \leq r<0.30)$, medium $(0.30 \leq r<0.50)$, or large $(r \geq 0.50)$.

\section{Results}

\subsection{Chromosome Microarray Analysis (CMA)}

We performed CMA in 90 females affected by idiopathic ASD, detecting $35 \mathrm{CNVs}$ (17 duplications and 18 deletions) in $29(32.2 \%)$. Twenty-three participants had one CNV and six carried 2 imbalances. Sixty-one f-ASD were considered $\mathrm{w}$-CNVs (67.8\% of the whole group).

Out of 35 CNVs, 25 were classified C-CNVS (71.4\%) and $10 \mathrm{~N}-\mathrm{CNVs}(28.6 \%)$. In the whole group of $90 \mathrm{f}-\mathrm{ASD}, 20$ patients harbored at least one possible disease-causing CNV (diagnostic yield 22.2\%) (Figure 1).

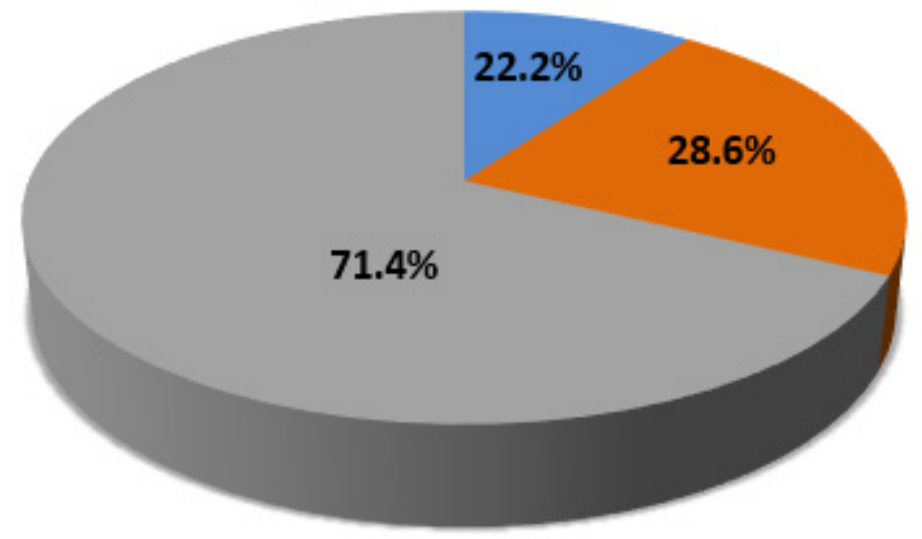

Figure 1. Graphical representation of chromosome microarray analysis (CMA) results in our group of 90 females affected by autism. In the pie chart is depicted the percentage of individuals with causative copy number variants (C-CNVs), non-causative copy number variants (N-CNVs) or without copy number variants ( $\mathrm{w}-\mathrm{CNVs})$. 
Table 1 illustrates the results of CMA investigations. There were not recurrent C-CNVs, with the exception of two unrelated subjects who harbored a 15q11-q13 microduplication. Ten CNVs involved genomic regions already associated with known contiguous gene-deletion/duplication syndromes associated with ASD or NDDs, 5 CNVs encompassed "high-confident" ASD-genes and ten involved genes reported in literature or in the SFARI Gene/Autism KB databases as possible candidates for autism.

The function and evidence of possible disease-association of the reported candidate-genes are summarized in Table 2. Bioinformatic analysis showed that 11 out of 21 of the reported disease-associated and candidate genes are involved in synaptic structure and transmission (ADARB1, ASIC2, CADM2, DMD, GRIN2A, GRM7, NEDD4, NRXN1, PCDH15, PTPRD, TRPM2) (Figure 2).

In $24 \mathrm{f}-\mathrm{ASD}$, carrying $29 \mathrm{CNVs}$, we assessed a de novo origin in 8 and a paternal in 12 , whereas CNVs were maternally-inherited in 9 patients. In 5 children we could not assess segregation because of lack of parental DNA. Table 3 shows the proportion of duplications and deletions and the mode of inheritance in relation to the different subtypes of CNVs. Overall, the rate of de novo CNV was $9.4 \%$. All de novo $\mathrm{CNV}$ involved known NDDs-associated genes/chromosomal regions. CNVs encompassing suggestive or "low confidence" ASD-genes were all inherited; 6 out 9 disrupted more than one NDD-gene or were associated with an additional C-CNV. Seven out of 9 maternally inherited vs. 6 out of 12 paternally inherited CNVs were causative. 
Table 1. Chromosomal microarray (CMA) results in the 29 participants carrying at least one Copy Number Variant (CNV). For each participant with positive CMA results are reported the genomic location and breakpoints of each $\mathrm{CNV}$, the $\mathrm{CNV}$ subtype (deletion or duplication), the size in base pairs, the inheritance status, the associated known genetic syndrome or Autism Spectrum Disorders (ASD) candidate genes involved in the rearrangement, and the CNV classification (causative or non-causative).

\begin{tabular}{|c|c|c|c|c|c|c|c|}
\hline ID. & CNV Breakpoints & CNV Type & Size (bp) & Inheritance & Syndrome/Candidate Gene & CNV Class & Reference \\
\hline \multirow{2}{*}{ P1 } & 22q13.33 (50781138-51219009) & del & 437,871 & de novo & Phelan-McDermid syndrome & $\mathrm{C}$ & \#MIM 606232 \\
\hline & Xp11.4 (38491539-38628756) & dup & 137,217 & mat & TSPAN7 & $\mathrm{C}$ & \#MIM 300210 \\
\hline P2 & $14 q 32.13(94817951-94883978)$ & del & 66,027 & - & - & $\mathrm{N}$ & - \\
\hline \multirow{2}{*}{ P3 } & 16p13.3 (6881091-7070689) & del & 189,598 & mat & RBFOX1 & $\mathrm{C}$ & [59] \\
\hline & 16p13.2 (9015110-10321593) & dup & $1,306,483$ & de novo & USP7, GRIN2A & C & [60] \\
\hline $\mathrm{P} 4$ & $21 \mathrm{q} 22.3(45822805-46530451)$ & dup & 707,646 & mat & ADARB1, TRPM2, ITGB2, SUMO3 & $\mathrm{C}$ & [61] \\
\hline P5 & $1 q 31.2(191644543-191775583)$ & del & 131,040 & pat & - & $\mathrm{N}$ & - \\
\hline P6 & 2q34.3 (214919902-215051057) & del & 131,155 & mat & - & $\mathrm{N}$ & - \\
\hline P7 & 1q21.2 (147211160-147824207) & dup & 613,047 & pat & - & $\mathrm{N}$ & - \\
\hline P8 & $17 \mathrm{p} 11.2(16822483-20193310)$ & del & $3,370,827$ & de novo & Smith-Magenis syndrome & $\mathrm{C}$ & \#MIM 182290 \\
\hline P9 & $15 q 21.3(56283008-56384604)$ & del & 101,596 & mat & NEDD4, RFX7 & $\mathrm{C}$ & [62] \\
\hline $\mathrm{P} 10$ & $17 q 12(34851537-36168104)$ & del & $1,316,567$ & de novo & 17q12 deletion syndrome & $\mathrm{C}$ & \#MIM 614527 \\
\hline P11 & 10q21.1 (55616917-55791973) & del & 175,056 & mat & PCDH15 & $\mathrm{C}$ & {$[63]$} \\
\hline \multirow{2}{*}{ P12 } & $4 q 34.1$ (172930618-173074943) & dup & 144,325 & pat & - & $\mathrm{N}$ & - \\
\hline & $4 q 34.2(176984739-177190235)$ & dup & 205,496 & pat & - & $\mathrm{N}$ & - \\
\hline P13 & $17 q 12(31953228-32922965)$ & dup & 969,737 & mat & ACCN1, TMEM132E & $\mathrm{C}$ & {$[64]$} \\
\hline \multirow{2}{*}{ P14 } & 3p12.1 (85615568-85672801) & del & 57,233 & pat & CADM2 & C & {$[32]$} \\
\hline & $3 p 26.1(7353126-7403750)$ & del & 50,624 & pat & GRM7 & $\mathrm{C}$ & [65] \\
\hline P15 & 7q31.1 (110954950-111202026) & del & 247,076 & pat & $I M M P 2 L$ & $\mathrm{C}$ & [66] \\
\hline P16 & 2q23.3 (153898093-154164672) & del & 266,579 & pat & - & $\mathrm{N}$ & - \\
\hline P17 & $5 q 23.3(129687092-130006500)$ & del & 319,408 & mat & - & $\mathrm{N}$ & - \\
\hline P18 & $15 q 11.2 q 13.1(23669701-28525460)$ & dup & $4,825,759$ & - & 15q11q13 duplication syndrome & $\mathrm{C}$ & \#MIM 608636 \\
\hline P19 & 2p16.1p15 (58566616-61546442) & del & $2,979,826$ & de novo & 2p16.1p15 deletion syndrome & $\mathrm{C}$ & \#MIM 612513 \\
\hline $\mathrm{P} 20$ & 16p11.2 (29673954-30197341) & dup & 523,387 & - & 16p11.2 duplication syndrome & $\mathrm{C}$ & \#MIM 614671 \\
\hline $\mathrm{P} 21$ & $15 q 11.2 q 13.1(23669701-28525460)$ & dup & $4,855,759$ & mat & 15q11-q13 duplication syndrome & $\mathrm{C}$ & \#MIM 608636 \\
\hline \multirow[b]{2}{*}{$\mathrm{P} 22$} & $9 p 24.1(7800020-8528849)$ & dup & 728,829 & - & PTPRD & $\mathrm{C}$ & [61] \\
\hline & Xp22.31 (6552712-8115153) & del & $1,562,441$ & - & Xp22.31 deletion syndrome & $\mathrm{C}$ & {$[67]$} \\
\hline $\mathrm{P} 23$ & 2p16.3 (48915312-48979903) & del & 64,591 & pat & - & $\mathrm{N}$ & - \\
\hline $\mathrm{P} 24$ & Xp22.33q28 (61529-155190083) & dup & $155,128,554$ & de novo & $47, X X X$ & $\mathrm{C}$ & [68] \\
\hline
\end{tabular}


Table 1. Cont

\begin{tabular}{|c|c|c|c|c|c|c|c|}
\hline ID. & CNV Breakpoints & CNV Type & Size (bp) & Inheritance & Syndrome/Candidate Gene & CNV Class & Reference \\
\hline P25 & Xp21.1 (31893344-32289012) & dup & 395,668 & de novo & $D M D$ & $\mathrm{C}$ & [69] \\
\hline $\mathrm{P} 26$ & 8q24.3 (146053353-146174033 & dup & 120,680 & - & - & $\mathrm{N}$ & - \\
\hline P27 & $\begin{array}{c}2 q 12.2 q 12.3 \\
(106929257-108403252)\end{array}$ & dup & $1,473,995$ & pat & ST6GAL2 & $\mathrm{C}$ & [70] \\
\hline P28 & 22q11.21 (20754422-21440514) & dup & 686,092 & pat & 22q11.2 duplication syndrome & $\mathrm{C}$ & \#MIM 608363 \\
\hline \multirow[b]{2}{*}{ P29 } & 2p16.2 (50909765-51083469) & del & 173,704 & pat & NRXN1 & $\mathrm{C}$ & [71] \\
\hline & Xp22.33 (581803-920279) & dup & 338,476 & de novo & SHOX & $\mathrm{C}$ & [72] \\
\hline
\end{tabular}

Pt: participant; CNV: copy number variant; bp: base pairs; del: deletion; dup: duplication; mat: maternal; pat: paternal; C: causative; N: non-causative.

Table 2. Function and evidences of disease-association of the reported candidate-genes encompassed in causative- Copy Number Variants (CNVs). The table reports evidences that supports the possible role in autism of the reported "high confidence" autism spectrum disorder (ASD) genes (genes with a Simons Foundation Autism Research Initiative SFARI Gene score $<3$ or with an Autism KB 2.0 score $>16$ ), and suggestive or "low confidence" candidate-genes (genes with a SFARI Gene score $\geq 3$ or with an AutismKB 2.0 score $\leq 16$ ). For each gene, genomic region, participant ID, function of the encoded protein and scores assigned in the SFARI Gene and AutismKB 2.0 databases are reported (NR: gene not reported in the database).

\begin{tabular}{|c|c|c|c|}
\hline Gene & Genomic Region (Participant ID) & Protein Function & SFARI Gene/AutismKB 2.0 \\
\hline \multicolumn{4}{|c|}{ "High confidence" ASD-genes } \\
\hline USP7 & $16 \mathrm{p} 13.2(\mathrm{P} 3)$ & Ubiquitin-specific protease; regulates ubiquitination processes & $2 / 4$ \\
\hline GRIN2A & $16 \mathrm{p} 13.2(\mathrm{P} 3)$ & Subunit 2A of the glutamate N-Methyl-D-Aspartate (NMDA) receptor & $2 / 10$ \\
\hline RBFOX1 & $16 \mathrm{p} 13.3(\mathrm{P} 3)$ & RNA-binding protein that regulates alternative splicing events & $2 / 28$ \\
\hline$D M D$ & Xp21.1 (P25) & $\begin{array}{l}\text { Component of the dystrophin-glycoprotein complex (DGC), which bridges the } \\
\text { inner cytoskeleton and the extracellular matrix }\end{array}$ & $\mathrm{S} / 28$ \\
\hline SHOX & Xp22.33 (P29) & $\begin{array}{l}\text { Belongs to the paired homeobox family, nuclear transcription factors involved in } \\
\text { cell-cycle and growth regulation }\end{array}$ & $2 / 2$ \\
\hline NRXN1 & 2p16.2 (P29) & $\begin{array}{l}\text { Cell adhesion molecule, form a complex with neuroligins at synapses in the } \\
\text { central nervous system required for neurotransmission and involved in the } \\
\text { formation of synaptic contacts. } \\
\text { Suggestive or "low confidence" candidate ASD-genes }\end{array}$ & $1 / 68$ \\
\hline TSPAN7 & Xp11.4 (P1) & $\begin{array}{l}\text { Member of the tetraspanin family, encodes a cell surface glycoprotein that } \\
\text { complex with integrins. It may have a role in neurite outgrowth and } \\
\text { Alpha-amino-3-hydroxy-5-methyl-4-isoxazolepropionate (AMPA) } \\
\text { receptor trafficking }\end{array}$ & $3 / 2$ \\
\hline ITGB2 & $21 \mathrm{q} 22.3(\mathrm{P} 4)$ & Integrin B2, adhesion molecule implicated in synaptic pruning & $\mathrm{NR} / 3$ \\
\hline
\end{tabular}


Table 2. Cont

\begin{tabular}{|c|c|c|c|}
\hline Gene & Genomic Region (Participant ID) & Protein Function & SFARI Gene/AutismKB 2.0 \\
\hline TRPM2 & $21 \mathrm{q} 22.3(\mathrm{P} 4)$ & $\begin{array}{l}\text { Voltage-independent cation channel, mediates sodium and calcium ion influx in } \\
\text { response to oxidative stress; modulates oxytocin release. }\end{array}$ & $\mathrm{NR} / 11$ \\
\hline$A D A R B 1$ & $21 \mathrm{q} 22.3(\mathrm{P} 4)$ & $\begin{array}{l}\text { Protein involved in the editing of the RNA of glutamate, serotonin and } \\
\text { Gamma-Aminobutyric Acid (GABA) receptors, and potassium } \\
\text { voltage-gated channels. }\end{array}$ & $5 / 1$ \\
\hline SUMO3 & $21 \mathrm{q} 22.3(\mathrm{P} 4)$ & $\begin{array}{l}\text { Involved in SUMOylation of proteins, a post-translational modification that } \\
\text { modulates the activity of several neuronal transcription factors }\end{array}$ & $\mathrm{NR} / 0$ \\
\hline RFX7 & $15 \mathrm{q} 21.3(\mathrm{P9})$ & Transcription factor & $\mathrm{NR} / 4$ \\
\hline NEDD4 & $15 \mathrm{q} 21.3(\mathrm{P} 9)$ & $\begin{array}{l}\text { Protein involved in the ubiquitin proteasome system. It plays a critical role in the } \\
\text { ubiquitination and degradation of AMPA receptors, endocytic machinery } \\
\text { components and Phosphatase and Tensin Homolog (PTEN) protein. }\end{array}$ & $\mathrm{NR} / 4$ \\
\hline PCDH15 & 10q21.1 (P11) & $\begin{array}{l}\text { Member of the cadherin superfamily, membrane proteins that mediate } \\
\text { cellular adhesion }\end{array}$ & $3 / 16$ \\
\hline $\begin{array}{l}\text { ACCN1 } \\
\text { (ASIC2) }\end{array}$ & 17q12 (P13) & $\begin{array}{l}\text { Non-voltage-dependent } \mathrm{Na}^{+} \text {channel; facilitates Acid-Sensing Ion Channel (ASIC) } \\
\text { localization to synapses interacting with synaptic scaffolding proteins as } \\
\text { Postsynaptic Density Protein } 95 \text { (PSD95) }\end{array}$ & $\mathrm{NR} / 7$ \\
\hline TMEM132E & 17q12 (P13) & Neural adhesion molecule & NR/NR \\
\hline CADM2 & 3p12.1 (P14) & $\begin{array}{l}\text { Adhesion molecule involved in synapse organization, providing regulated } \\
\text { trans-synaptic adhesion. }\end{array}$ & $3 / 0$ \\
\hline GRM7 & 3p26.1 (P14) & Metabotropic glutamate receptor mGluR7 & $3 / 12$ \\
\hline$I M M P 2 L$ & 7q31.1 (P15) & $\begin{array}{l}\text { Subunit of an inner mitochondrial membrane peptidase complex involved in } \\
\text { processing of mitochondrial proteins }\end{array}$ & $3 / 10$ \\
\hline PTPRD & 9p23p24 (P22) & $\begin{array}{l}\text { Receptor protein tyrosine phosphatase, induces pre- and post-synaptic } \\
\text { differentiation and regulates neurogenesis. Interacts with proteins involved in } \\
\text { intellectual disability/ASD as IL1RAP and IL1RAPL1 and proteins of the } \\
\text { mitogen-activated protein kinase (MEK)/extracellular signal-regulated kinase } \\
\text { (ERK) pathway. }\end{array}$ & $\mathrm{NR} / 7$ \\
\hline ST6GAL2 & $2 q 12.3($ P27) & $\begin{array}{l}\text { Encodes a sialyltransferase mostly expressed in embryonic and adult brain. CNVs } \\
\text { were reported in autism studies. }\end{array}$ & $\mathrm{NR} / 2$ \\
\hline
\end{tabular}


A

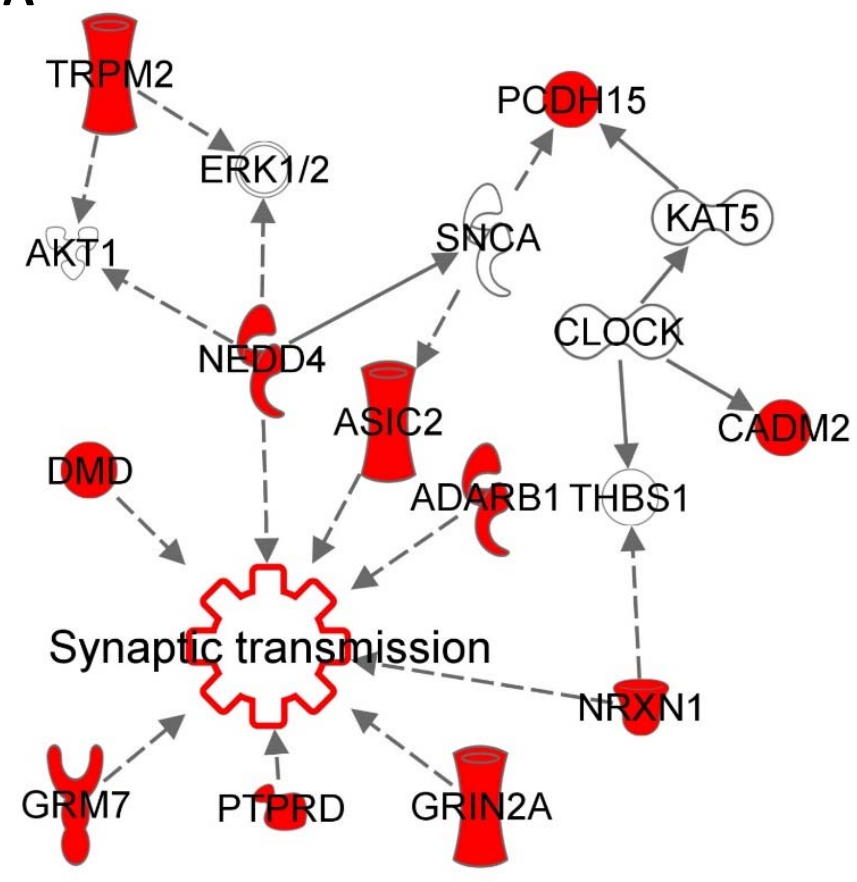

B

$-\log 10 \mathrm{p}$ value

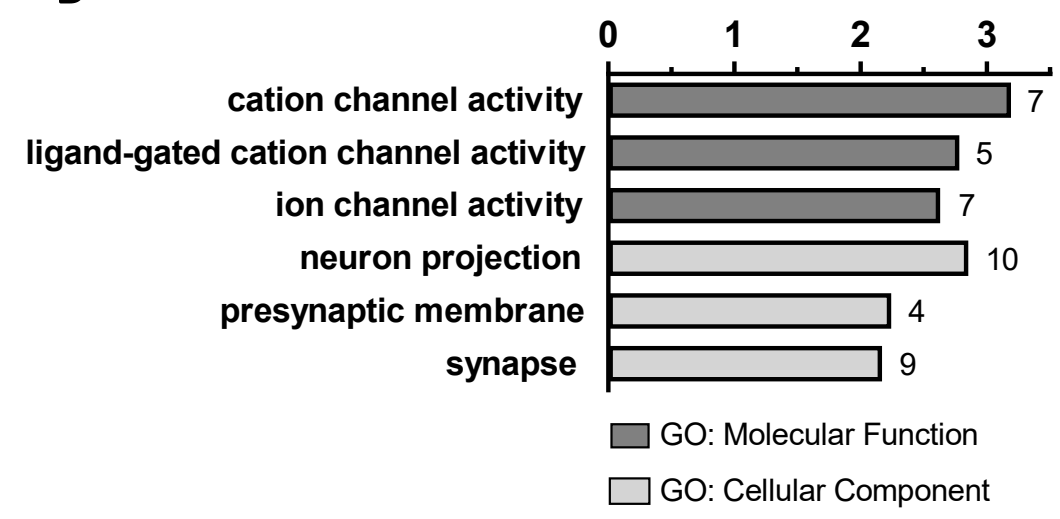

Figure 2. Bioinformatic analyses performed on ASD-candidate genes encompassed by C-CNVs. (A) A Core analysis run in Variant Effects Analysis mode using the Ingenuity Pathway Analysis software figured out cellular processes related to our gene dataset (21 genes) generating a functional network encompassing 11 genes (in red). Synaptic transmission resulted the most significant functional annotation ( $p$-value $6.05 \times 10^{-9}$ ). Bridging nodes (in white) were denoted evaluating both direct and indirect interactions related only to neurological diseases and with stringent level of confidence (B). Gene ontology (GO) categorization was carried out using ToppGene Suite. Top three ontologies for Molecular Function (dark grey) and Cellular Component (light grey) were annotated; statistical significance of GO terms was reported as - $\log 10$ ( $p$-value). The number of genes belonging to each category was reported on the right of each bar.

\subsection{Phenotypic Characterization}

Twenty-seven f-ASD had an absence of language whereas 63 were "verbal".

Cognitive evaluation was performed in 87 participants, being three participants unfit for psychometric testing. Forty-two of the tested individuals had IQ $\leq 70$ and 45 had IQ $\geq 70$. 
The 67 participants tested with ADOS-2 had the following mean (SD) Total, SA and RRB ADOS CSS, respectively: 6.57 (2.36), 6.79 (2.34), and 7.22 (2.30).

Supplementary Table S1 recapitulates clinical data of the studied population.

Table 3. Proportion of deletions vs. duplications and pattern of inheritance of the reported CNVs according to their classification (causative vs. non-causative).

\begin{tabular}{cccccc}
\hline & \multicolumn{2}{c}{ Type of CNVs } & \multicolumn{3}{c}{ Inheritance } \\
\cline { 2 - 6 } & $\begin{array}{c}\text { Duplication } \\
(\boldsymbol{n}=\mathbf{1 7})\end{array}$ & $\begin{array}{c}\text { Deletion } \\
(\boldsymbol{n}=\mathbf{1 8})\end{array}$ & $\begin{array}{c}\text { De novo } \\
(\boldsymbol{n}=\mathbf{8})\end{array}$ & $\begin{array}{c}\text { Paternal } \\
(\boldsymbol{n}=\mathbf{1 2})\end{array}$ & $\begin{array}{c}\text { Maternal } \\
(\boldsymbol{n}=\mathbf{9})\end{array}$ \\
\hline $\begin{array}{c}\text { C-CNVs } \\
(n=25)\end{array}$ & $13 / 25(52 \%)$ & $12 / 25(48 \%)$ & $8 / 21(38.1 \%)$ & $6 / 21(28.6 \%)$ & $7 / 21(33.3 \%)$ \\
$\begin{array}{c}\mathrm{N}-\mathrm{CNVs} \\
(n=10)\end{array}$ & $4 / 10(40 \%)$ & $6 / 10(60 \%)$ & $0 / 8(0 \%)$ & $6 / 8(75 \%)$ & $2 / 8(25 \%)$ \\
Total & $17 / 35$ & $18 / 35$ & $8 / 29(27.6 \%)$ & $\begin{array}{c}12 / 29 \\
(41.4 \%)\end{array}$ & $9 / 29(31 \%)$ \\
\hline
\end{tabular}

Note: Inheritance was assessed in 29 out of $35 \mathrm{CNVs}$. C-CNVs = causative CNVs; N-CNVs = non-causative CNVs; $n=$ number of CNVs for each group.

\subsection{Statistical Analysis}

We observed a statistically significant association between the heritage (de novo vs. maternal and paternal) and the subtypes of CNVs (C-CNVs vs. N-CNVs) $\left(\mathrm{Chi}^{2}{ }_{(1)}=4.21, p=0.04\right)$. Indeed, all N-CNVs were transmitted and never arose de novo while all de novo CNVs were causative ( $38 \%$ of C-CNVs); 7 out of $9(77.8 \%)$ C-CNVs were maternal and 6 out of $12(50 \%)$ were paternal.

Whilst the type of genomic micro-rearrangement (deletion vs. duplication) was not statistically correlated to causative/non-causative definition $\left(\mathrm{Chi}^{2}{ }_{(1)}=0.41, p=0.52\right)$, not considering CNVs associated with contiguous-gene syndromes, most of the breakpoints of causative duplications lie within at least one NDD-candidate gene $(n=6 / 8)$. C-CNVs had a CNVs burden value statistical significantly higher than those of the N-CNVs subtypes (mean (SD) $=1.14(1.43)$ vs. $0.19(0.16)$; Mann-Whitney $U=52.50, z=2.56, p=0.01, r=0.49$ ).

Table 4 shows the age, the cognitive and linguistic level as well as the autism severity of the three groups of individuals according to different $\mathrm{CNV}$ subtypes (causative, non-causative and without CNVs).

To investigate whether there were significant differences in clinical features between groups, we regrouped participants with negative CMA results ( $\mathrm{N}-\mathrm{CNVs}$ and $\mathrm{w}-\mathrm{CNVs}$ ) and compared their characteristics with cases with $\mathrm{C}-\mathrm{CNVs}$. The two groups resulted matched for age [mean (SD) $=66.95$ (38.55) vs. 56.74 (38.03); Mann-Whitney $U=523.00, z=1.72, p=0.09$ ].

We found that there were no differences between the two groups on the cognitive level (IQ $\leq 70$ vs. IQ $>70 ; C^{2} i^{2}{ }_{(1)}=0.47, p=0.49$ ), language level (non-verbal vs. verbal; $C h i^{2}{ }_{(1)}=0.31, p=0.58$ ), and on the CSS obtained on the total score and on the AS ADOS domain (Mann-Whitney $U=262.50$, $z=1.42, p=0.16$; Mann-Whitney $U=303.00, z=0.77, p=0.44$ ).

The relative frequencies of the phenotypic features were the following: in the group with C-CNVs, $55 \%(11 / 20)$ had IQ $\leq 70 ; 60 \%$ had a moderate-severe level of autism symptoms $(9 / 15), 35 \%$ had absence of language (7/20); in the group with negative CMA, 46\% (31/37) had IQ $\leq 70 ; 75 \%$ had a moderate-severe level of autism symptoms (47/62), 28\% had absent language (20/70).

Conversely, we found that the f-ASD with C-CNVs had a statistically significantly lower CSS on the RRB ADOS domain that those without CNVs or with non-causative (mean (SD) $=6.08$ (2.14) vs. 7.50 (2.27); Mann-Whitney $U=197, z=2.48, p=0.01, r=0.30$ ). 
Table 4. Demographic features of participants grouped according to CMA results. For each group (with causative and non-causative $\mathrm{CNVs}$, or without $\mathrm{CNVs}$ ) are reported the mean age at the last examination (in months), the rate of patients with a IQ level $>70 \mathrm{vs.} \leq 70$, the rate of verbal vs. non-verbal patients, and the mean calibrated severity scores (CSS) of the global Autism Diagnostic Observation Schedule (ADOS) scores and the sub-scores of the Social Affect (SA) and Restricted and Repetitive Behaviors (RRB) domains. The language level was assessed in all 90 participants, the IQ level and the ADOS scores were available for 87 and 67 of the 90 individuals, respectively.

\begin{tabular}{cccc}
\hline Mean age at the last examination & $\begin{array}{c}\text { C-CNVs } \\
(\boldsymbol{n}=\mathbf{2 0})\end{array}$ & $\begin{array}{c}\text { N-CNVs } \\
(\boldsymbol{n}=\mathbf{9})\end{array}$ & $\begin{array}{c}\text { w-CNVs } \\
(\boldsymbol{n}=\mathbf{6 1})\end{array}$ \\
\hline $\begin{array}{c}\text { in months (SD) } \\
\text { IQ }>70\end{array}$ & $66.95(38.55)$ & $47.11(15.57)$ & $58.16(40.19)$ \\
IQ $\leq 70$ & $9 / 20(45 \%)$ & $4 / 8(50 \%)$ & $32 / 59(54.2 \%)$ \\
Verbal & $11 / 20(55 \%)$ & $4 / 8(50 \%)$ & $27 / 59(45.8 \%)$ \\
\hline Non-verbal & $13 / 20(65 \%)$ & $5 / 9(55.6 \%)$ & $45 / 61(73.7 \%)$ \\
\hline Mean ADOS-CSS: & $7 / 20(35 \%)$ & $4 / 9(44.4 \%)$ & $16 / 61(26.3 \%)$ \\
Mean SA-CSS (SD) & - & - & - \\
Mean RRB-CSS (SD) & $6.38(2.26)$ & $7.50(1.64)$ & $6.81(2.45)$ \\
Mean Global-CSS (SD) & $6.08(2.14)$ & $5.50(3.83)$ & $7.75(1.92)$ \\
\hline
\end{tabular}

$\mathrm{C}-\mathrm{CNVs}=$ participants with causative $\mathrm{CNVs} ; \mathrm{N}-\mathrm{CNVs}=$ participants with non-causative CNVs; $\mathrm{w}-\mathrm{CNVs}=$ participants without; $n=$ number of patients for each group; $\mathrm{SD}=$ standard deviation .

\section{Discussion}

Although a recent meta-analysis and multidisciplinary consensus statement proposes exome sequencing at the beginning of the evaluation of unexplained neurodevelopmental disorders [73], CMA is still the recommended first-tier genetic analysis in the evaluation of ASD subjects [40,74].

In the last few years, investigations of large cohorts of ASD individuals $[13,37,75]$ have identified a high burden of CNVs with rare C-CNVs being found in 5-10\% of idiopathic ASD [76]. However, these data are often affected by gender-bias due to the high $\mathrm{M} / \mathrm{F}$ ratio in the vast majority of the studies and even more recent investigations addressing type and frequency of C-CNVs did not allowwith few exceptions-for separate gender examinations due to relatively small sample size [77-80].

Herein, we focused exclusively on a cohort of f-ASD and we found clinically significant CNVs in about $22 \%$ of patients. Few investigations have considered CNVs and clinical features in $\mathrm{f}$-ASD in comparison with ASD males. In one study, large CNVs (>400 kb) were more frequent in $\mathrm{f}$-ASD than in males (29\% vs. 16\%), and this difference was even higher (F/M 3:1) if analyses were limited to regions containing genes involved in NDDs [81]. In a similar vein, Levy and colleagues (2011) [13] detected that f-ASD have a high frequency of de novo CNVs (11.7\% vs. 7.4\% in males), and Sanders et al. (2015) [15] identified a significant difference in the rate of de novo CNVs between boys (5.3\%) and girls (8.7\%). Our numbers in an only girl cross-sectional, monocentric study denote a similar sex effect with a high diagnostic yield and a $9.4 \%$ occurrence of de novo variants.

All de novo CNVs involved known NDDs-associated chromosomal regions whereas CNVs encompassing suggestive or "low confidence" ASD-genes were all inherited and mostly disrupting more than one NDD-gene or associated with an additional C-CNV. Among C-CNVs, there was an excess of maternally-inherited potentially pathogenic CNVs. These findings support the "two-hit model" suggested in previous studies in which the compound effect of a small number of rare variants may contribute to phenotypic heterogeneity of ASD [82].

While literature in the ASD field reported an excess of clinically-significant deletions, we did not find a correlation between the type of genomic rearrangement and causative/non causative definition. Haploinsufficiency for genes within a deletion is a well-recognized cause of genetic disease. Conversely, interpreting the phenotypic consequences of microduplications is often challenging 
because the pathogenicity of most duplications cannot be explained by triplosensitivity. Sequencing the breakpoints of 119 duplications, Newman et al. (2015) demonstrated that, rather than an extra copy effect, the phenotype of microduplications can be related to the misregulation of genes that span the breakpoints, through loss-of-function mechanisms due to altered transcription or translation or to the creation of fusion proteins with unknown functions [83]. In our f-ASD cohort, most of the causative non-syndromic duplications breakpoints disrupted at least one NDD-candidate gene, hence we can suppose that the pathogenic phenotype could be caused by similar mechanisms.

Unlike previous literature results [78], we did not find any association between C-CNVs and IQ or language deficits. Analyzing the phenotypic features of females with C-CNVs versus those with negative CMA results, we only observed statistically significantly lower scores on the restricted repetitive behaviors (RRB) ADOS domain in f-ASD with clinically significant variants. Recently, Barone et al. reported more severe autistic symptoms in individuals with C-CNVs [79]. The discrepancies with our data could reflect the diverse characteristics of the studied population, indeed several studies suggested a sex effect on RRB scores, which are reported to be repeatedly lower in female than in male subgroups [28,84-86]. Crucially, several lines of evidence suggest that social-communication (SC) and RRB symptom domains are underpinned by different genetic mechanisms. For instance, a recent genome-wide association study demonstrated that the RRB trait "systemizing" is heritable and genetically correlated with autism in the general population and that the SC and RRB domains in autistic subjects show low shared genetics [87]. In particular, the contribution of genetic factors to the RRB domain is sustained by their significative presence on both parents [88] and siblings [89] of probands with ASD. Overall, the impact of C-CNVs on ASD symptoms is still unclear and a recent work highlighted the contribution of environmental factors (i.e., maternal infections during pregnancy) on RRB severity in individuals with CNVs [90]. We can only speculate that we registered lower RRB scores in our f-ASD with positive CMA results because this sample represents the mild-end of a genomic "simple" disorder, while those girls with negative results could reflect the group of f-ASD with "complex" multifactorial etiology, as the largest portion of idiopathic autistic males.

With the exception of two subjects with a 15q11-q13 microduplication, no overlapping CNVs were detected, confirming the high genetic heterogeneity of ASD. Fifteen CNVs involved ASD/NDDs-associated genes or genomic regions already identified, whereas $10 \mathrm{CNVs}$ encompassed genes reported as possible candidates for ASD in literature or in ASD databases (Tables 1 and 2). The contribution of each CNV to the phenotype of our f-ASD patients is discussed in the Supplementary File S1. Out of this list, some cases appear worth discussing.

The known contiguous-gene deletion/duplication syndromes detected in our cases were associated with a diagnosis of "idiopathic" ASD because these patients did not display any of the additional non-neurodevelopmental features specific of these syndromes, as dysmorphisms or congenital defects which can be seen in Smith-Magenis (P8), 17q12 microdeletion (P10), 2p15p16 deletion (P19), 22q11 duplication (P28) and SHOX duplication (P29) syndromes. These patients could represent the mild-end of the phenotypic spectrum of these genomic disorders, due to the "NDDs-protective effect" reported in females [16].

In some cases, reverse phenotyping allowed the investigation and prevention of important comorbidities, as in P25, who carries a de novo partial duplication of the DMD gene, which in females could manifest with muscle weakness and cardiomyopathy, and in P20, who carries a 16p11.2 duplication widely reported in ASD studies which is associated with the risk of developing psychotic symptoms [91].

Among clinically relevant rearrangements, aneuploidy was identified in a single subject, who presented an X chromosome trisomy $(47, X X X)$. Interestingly, data in the literature did not report a greater risk for autism in $X$ chromosome trisomy [92], even if difficulties in social functioning and, more broadly, an increased vulnerability for autistic traits are described [68].

The de novo 16p13 duplication detected in one patient (P3) involves partially UPS7. Variants affecting this gene were recently reported in 23 individuals with syndromic Developmental 
Delay/Intellectual Disability [93], and about half of reported subjects had ASD. P3 presents mild motor developmental delay, absent speech, behavioral anomalies and ASD, suggesting that USP7 haploinsufficiency should be suspected in a case of ASD with absence of speech and behavioral disorders. CNVs detected in P3 spans also GRIN2A and RBFOX1, so we cannot exclude a possible additional role of these genes in the phenotype of the patient.

The deletions found in P11, P14 and P15 reinforce the evidence of a possible contribution of PCDH15, GRM7, CADM2 and IMMP2L genes to ASD susceptibility.

Finally, five CNVs spanned some "low-confidence" ASD-genes, which can be investigated in future studies (i.e., TRPM2, ADARB1, RFX7, NEDD4, ASIC2, PTPRD, ST6GAL2).

When new and old genes pinpointed by CMA studies were combined in functional modules using IPA and ToppGene Suite, we observed an enrichment in genes involved in synaptic function and transmission, which are well-established biological processes involved in autism and NDDs [94].

In conclusion, this study provides a representative picture of the spectrum of CNV in $\mathrm{f}-\mathrm{ASD}$ investigated in a clinical setting. As expected, no specific CNVs have been found to be required for developing ASD, supporting the heterogeneity of affected molecular pathways. However, genes in the C-CNVs of our sample of f-ASD code mainly for proteins that could be grouped in two different functional systems: synaptic function/structure, and mRNA/protein processing. Of note, environmental exposures during specific windows of vulnerabilities in prenatal and perinatal life critically interact with genetic susceptibility contributing to ASD pathogenesis [95]. Our study suggests that females with idiopathic ASD have a high rate of pathogenic CNVs encompassing both known and new candidate ASD genes. Hence, studies on large samples of f-ASD carefully assessed from a clinical point of view could help in unraveling the genetic determinants of autism. Moreover, f-ASD with normal-array comparative genomic hybridization analysis could benefit from whole exome or genome sequencing [96], paving the way for the implementation of personalized treatments based on genetic findings.

Supplementary Materials: The following are available online at http://www.mdpi.com/2075-4426/10/4/160/s1, Table S1: Phenotipic characteristics of participants; Supplementary File S1: Contribution of each CNV to the phenotype of f-ASD patients.

Author Contributions: Conceptualization of the article, S.C., I.R., G.B., F.M.S., F.M.; Major contributors in writing the manuscript, S.C., I.R.; Sample collection and clinical characterization of patients, A.C., R.T.; Data Acquisition, R.C., D.T.; Statistical Analyses, G.B.; Genetic Analyses, D.C., S.D.; Contributed to review and editing the manuscript, F.M.S., F.M. All authors have read and agreed to the published version of the manuscript.

Funding: This work has been partially supported by grant from the IRCCS Fondazione Stella Maris (Ricerca Corrente, and the " $5 \times 1000$ " voluntary contributions, Italian Ministry of Health). S.C. was partially funded by AIMS-2-Trials.

Acknowledgments: We gratefully acknowledge all the subjects who have participated in the study.

Conflicts of Interest: The authors declare that they have no conflict of interest.

Ethical Statement: The study was conducted in accordance with the Declaration of Helsinki, and the protocol was approved by the Pediatric Ethic Committee of Tuscany Region.

\section{References}

1. American Psychiatric Association. Diagnostic and Statistical Manual of Mental Disorders (DSM-5 $\left.{ }^{\circledR}\right)$; American Psychiatric Publication: Washington, DC, USA, 2013.

2. Muhle, R.A.; Reed, H.E.; Stratigos, K.A.; Weele, J.V.-V. The Emerging Clinical Neuroscience of Autism Spectrum Disorder: A Review. JAMA Psychiatry 2018, 75, 514-523. [CrossRef]

3. Kim, J.Y.; Son, M.J.; Son, C.Y.; Radua, J.; Eisenhut, M.; Gressier, F.; Koyanagi, A.; Carvalho, A.F.; Stubbs, B.; Solmi, M.; et al. Environmental risk factors and biomarkers for autism spectrum disorder: An umbrella review of the evidence. Lancet Psychiatry 2019, 6, 590-600. [CrossRef]

4. Maenner, M.J.; Shaw, K.A.; Baio, J.; Washington, A.; Patrick, M.; DiRienzo, M.; Christensen, D.L.; Wiggins, L.D.; Pettygrove, S.; Andrews, J.G.; et al. Prevalence of Autism Spectrum Disorder among Children Aged 8 Years-Autism and Developmental Disabilities Monitoring Network, 11 Sites, United States, 2016. MMWR Surveill. Summ. 2020, 69, 1-12. [CrossRef] 
5. Narzisi, A.; Posada, M.; Barbieri, F.; Chericoni, N.; Ciuffolini, D.; Pinzino, M.; Romano, R.; Scattoni, M.L.; Tancredi, R.; Calderoni, S.; et al. Prevalence of Autism Spectrum Disorder in a large Italian catchment area: A school-based population study within the ASDEU project. Epidemiol. Psychiatr. Sci. 2018, 29, e5. [CrossRef]

6. Kanner, L. Autistic disturbances of affective contact. Nerv. Child 1943, 2, 217-250.

7. Asperger, H. Die "Autistischen Psychopathen" im Kindesalter. Arch. Psychiatr. Nervenkr. 1944, 117, 76-136. [CrossRef]

8. Wing, L. Sex ratios in early childhood autism and related conditions. Psychiatry Res. 1981, 5, $129-137$. [CrossRef]

9. Lord, C.; Schopler, E. Neurobiological Implications of Sex Differences in Autism. In Neurobiological Issues in Autism; Schopler, E., Mesibov, G., Eds.; Plenum Press: New York, NY, USA, 1987; pp. 191-211.

10. Loomes, R.; Hull, L.; Mandy, W.P.L. What Is the Male-to-Female Ratio in Autism Spectrum Disorder? A Systematic Review and Meta-Analysis. J. Am. Acad. Child Adolesc. Psychiatry 2017, 56, 466-474. [CrossRef]

11. McCarthy, M.M.; Wright, C.L. Convergence of Sex Differences and the Neuroimmune System in Autism Spectrum Disorder. Biol. Psychiatry 2017, 81, 402-410. [CrossRef] [PubMed]

12. Werling, D.M.; Parikshak, N.N.; Geschwind, D.H. Gene expression in human brain implicates sexually dimorphic pathways in autism spectrum disorders. Nat. Commun. 2016, 7, 10717. [CrossRef] [PubMed]

13. Levy, D.; Ronemus, M.; Yamrom, B.; Lee, Y.; Leotta, A.; Kendall, J.; Marks, S.; Lakshmi, B.; Pai, D.; Ye, K.; et al. Rare de novo and transmitted copy-number variation in autistic spectrum disorders. Neuron 2011, 70, 886-897. [CrossRef] [PubMed]

14. Sanders, S.J.; Ercan-Sencicek, A.G.; Hus, V.; Luo, R.; Murtha, M.T.; Moreno-De-Luca, D.; Chu, S.H.; Moreau, M.P.; Gupta, A.R.; Thomson, S.A.; et al. Multiple recurrent de novo CNVs, including duplications of the 7q11.23 Williams syndrome region, are strongly associated with autism. Neuron 2011, 70, 863-885. [CrossRef]

15. Sanders, S.J.; He, X.; Willsey, A.J.; Ercan-Sencicek, A.G.; Samocha, K.E.; Cicek, A.E.; Murtha, M.T.; Bal, V.H.; Bishop, S.L.; Dong, S.; et al. Insights into Autism Spectrum Disorder Genomic Architecture and Biology from 71 Risk Loci. Neuron 2015, 87, 1215-1233. [CrossRef]

16. Desachy, G.; Croen, L.A.; Torres, A.R.; Kharrazi, M.; Delorenze, G.N.; Windham, G.C.; Yoshida, C.K.; Weiss, L.A. Increased female autosomal burden of rare copy number variants in human populations and in autism families. Mol. Psychiatry 2015, 20, 170-175. [CrossRef] [PubMed]

17. Neale, B.M.; Kou, Y.; Liu, L.; Ma'ayan, A.; Samocha, K.E.; Sabo, A.; Lin, C.-F.; Stevens, C.; Wang, L.-S.; Makarov, V.; et al. Patterns and rates of exonic de novo mutations in autism spectrum disorders. Nature 2012, 485, 242-245. [CrossRef] [PubMed]

18. O'Roak, B.J.; Vives, L.; Girirajan, S.; Karakoc, E.; Krumm, N.; Coe, B.P.; Levy, R.; Ko, A.; Lee, C.; Smith, J.D.; et al. Sporadic autism exomes reveal a highly interconnected protein network of de novo mutations. Nature 2012, 485, 246-250. [CrossRef] [PubMed]

19. Sanders, S.J.; Murtha, M.T.; Gupta, A.R.; Murdoch, J.D.; Raubeson, M.J.; Willsey, A.J.; Ercan-Sencicek, A.G.; DiLullo, N.M.; Parikshak, N.N.; Stein, J.L.; et al. De novo mutations revealed by whole-exome sequencing are strongly associated with autism. Nature 2012, 485, 237-241. [CrossRef]

20. Iossifov, I.; Ronemus, M.; Levy, D.; Wang, Z.; Hakker, I.; Rosenbaum, J.; Yamrom, B.; Lee, Y.-H.; Narzisi, G.; Leotta, A.; et al. De novo gene disruptions in children on the autistic spectrum. Neuron 2012, 74, 285-299. [CrossRef]

21. Mitra, I.; Tsang, K.; Ladd-Acosta, C.; Croen, L.A.; Aldinger, K.A.; Hendren, R.L.; Traglia, M.; Lavillaureix, A.; Zaitlen, N.; Oldham, M.C.; et al. Pleiotropic Mechanisms Indicated for Sex Differences in Autism. PLoS Genet. 2016, 12, e1006425. [CrossRef]

22. Van Wijngaarden-Cremers, P.J.M.; van Eeten, E.; Groen, W.B.; Van Deurzen, P.A.; Oosterling, I.J.; Van der Gaag, R.J. Gender and age differences in the core triad of impairments in autism spectrum disorders: A systematic review and meta-analysis. J. Autism Dev. Disord. 2014, 44, 627-635. [CrossRef]

23. Banach, R.; Thompson, A.; Szatmari, P.; Goldberg, J.; Tuff, L.; Zwaigenbaum, L.; Mahoney, W. Brief Report: Relationship between non-verbal IQ and gender in autism. J. Autism Dev. Disord. 2009, 39, 188-193. [CrossRef]

24. Carter, A.S.; Black, D.O.; Tewani, S.; Connolly, C.E.; Kadlec, M.B.; Tager-Flusberg, H. Sex differences in toddlers with autism spectrum disorders. J. Autism Dev. Disord. 2007, 37, 86-97. [CrossRef] [PubMed] 
25. Holtmann, M.; Bölte, S.; Poustka, F. Autism spectrum disorders: Sex differences in autistic behaviour domains and coexisting psychopathology. Dev. Med. Child Neurol. 2007, 49, 361-366. [CrossRef] [PubMed]

26. Duvekot, J.; van der Ende, J.; Verhulst, F.C.; Slappendel, G.; van Daalen, E.; Maras, A.; Greaves-Lord, K. Factors influencing the probability of a diagnosis of autism spectrum disorder in girls versus boys. Autism 2017, 21, 646-658. [CrossRef]

27. Hartley, S.L.; Sikora, D.M. Sex differences in autism spectrum disorder: An examination of developmental functioning, autistic symptoms, and coexisting behavior problems in toddlers. J. Autism Dev. Disord. 2009, 39, 1715-1722. [CrossRef]

28. Tillmann, J.; Ashwood, K.; Absoud, M.; Bölte, S.; Bonnet-Brilhault, F.; Buitelaar, J.K.; Calderoni, S.; Calvo, R.; Canal-Bedia, R.; Canitano, R.; et al. Evaluating Sex and Age Differences in ADI-R and ADOS Scores in a Large European Multi-site Sample of Individuals with Autism Spectrum Disorder. J. Autism Dev. Disord. 2018, 48, 2490-2505. [CrossRef] [PubMed]

29. Andersson, G.W.; Gillberg, C.; Miniscalco, C. Pre-school children with suspected autism spectrum disorders: Do girls and boys have the same profiles? Res. Dev. Disabil. 2013, 34, 413-422. [CrossRef]

30. Postorino, V.; Fatta, L.M.; De Peppo, L.; Giovagnoli, G.; Armando, M.; Vicari, S.; Mazzone, L. Longitudinal comparison between male and female preschool children with autism spectrum disorder. J. Autism Dev. Disord. 2015, 45, 2046-2055. [CrossRef] [PubMed]

31. Messinger, D.S.; Young, G.S.; Webb, S.J.; Ozonoff, S.; Bryson, S.E.; Carter, A.; Carver, L.; Charman, T.; Chawarska, K.; Curtin, S.; et al. Early sex differences are not autism-specific: A Baby Siblings Research Consortium (BSRC) study. Mol. Autism 2015, 6, 32. [CrossRef]

32. Casey, J.P.; Magalhaes, T.; Conroy, J.M.; Regan, R.; Shah, N.; Anney, R.; Shields, D.C.; Abrahams, B.S.; Almeida, J.; Bacchelli, E.; et al. A novel approach of homozygous haplotype sharing identifies candidate genes in autism spectrum disorder. Hum. Genet. 2012, 131, 565-579. [CrossRef]

33. Zwaigenbaum, L.; Bryson, S.E.; Szatmari, P.; Brian, J.; Smith, I.M.; Roberts, W.; Vaillancourt, T.; Roncadin, C. Sex differences in children with autism spectrum disorder identified within a high-risk infant cohort. J. Autism Dev. Disord. 2012, 42, 2585-2596. [CrossRef] [PubMed]

34. Ben-Itzchak, E.; Ben-Shachar, S.; Zachor, D.A. Specific neurological phenotypes in autism spectrum disorders are associated with sex representation. Autism Res. 2013, 6, 596-604. [CrossRef]

35. Amiet, C.; Gourfinkel-An, I.; Bouzamondo, A.; Tordjman, S.; Baulac, M.; Lechat, P.; Mottron, L.; Cohen, D. Epilepsy in autism is associated with intellectual disability and gender: Evidence from a meta-analysis. Biol. Psychiatry 2008, 64, 577-582. [CrossRef] [PubMed]

36. Cheung, S.W.; Shaw, C.A.; Yu, W.; Li, J.; Ou, Z.; Patel, A.; Yatsenko, S.A.; Cooper, M.L.; Furman, P.; Stankiewicz, P.; et al. Development and validation of a CGH microarray for clinical cytogenetic diagnosis. Genet. Med. 2005, 7, 422-432. [CrossRef]

37. Sebat, J.; Lakshmi, B.; Malhotra, D.; Troge, J.; Lese-Martin, C.; Walsh, T.; Yamrom, B.; Yoon, S.; Krasnitz, A.; Kendall, J.; et al. Strong association of de novo copy number mutations with autism. Science 2007, 316, 445-449. [CrossRef]

38. Baio, J.; Wiggins, L.; Christensen, D.L.; Maenner, M.J.; Daniels, J.; Warren, Z.; Kurzius-Spencer, M.; Zahorodny, W.; Rosenberg, C.R.; White, T.; et al. Prevalence of Autism Spectrum Disorder among Children Aged 8 Years-Autism and Developmental Disabilities Monitoring Network, 11 Sites, United States, 2014. MMWR Surveill. Summ. 2018, 67, 1-23. [CrossRef] [PubMed]

39. Committee on Bioethics, Committee on Genetics, and the American College of Medical Genetics and Genomics Social, Ethical, and Legal Issues Committee. Ethical and Policy Issues in Genetic Testing and Screening of Children. Pediatrics 2013, 131, 620-622. [CrossRef]

40. Manning, M.; Hudgins, L. Professional Practice and Guidelines Committee Array-based technology and recommendations for utilization in medical genetics practice for detection of chromosomal abnormalities. Genet. Med. 2010, 12, 742-745. [CrossRef]

41. Volkmar, F.; Siegel, M.; Woodbury-Smith, M.; King, B.; McCracken, J.; State, M.; American Academy of Child and Adolescent Psychiatry (AACAP) Committee on Quality Issues (CQI). Practice parameter for the assessment and treatment of children and adolescents with autism spectrum disorder. J. Am. Acad. Child Adolesc. Psychiatry 2014, 53, 237-257. [CrossRef]

42. Cannon, B.; Pan, C.; Chen, L.; Hadd, A.G.; Russell, R. A dual-mode single-molecule fluorescence assay for the detection of expanded CGG repeats in Fragile X syndrome. Mol. Biotechnol. 2013, 53, 19-28. [CrossRef] 
43. Tammimies, K.; Marshall, C.R.; Walker, S.; Kaur, G.; Thiruvahindrapuram, B.; Lionel, A.C.; Yuen, R.K.C.; Uddin, M.; Roberts, W.; Weksberg, R.; et al. Molecular Diagnostic Yield of Chromosomal Microarray Analysis and Whole-Exome Sequencing in Children With Autism Spectrum Disorder. JAMA 2015, 314, 895-903. [CrossRef]

44. Miles, J.H.; Takahashi, T.N.; Bagby, S.; Sahota, P.K.; Vaslow, D.F.; Wang, C.H.; Hillman, R.E.; Farmer, J.E. Essential versus complex autism: Definition of fundamental prognostic subtypes. Am. J. Med. Genet. Part A 2005, 135, 171-180. [CrossRef]

45. Griffiths, R. The Griffiths Mental Developmental Scales, Revised. Henley: Association for Research in Infant and Child Development; Test Agency: Oxford, UK, 1996.

46. Wechsler, D. WPPSI-III Wechsler Preschool and Primary Scale of Intelligence-III. Adattamento Italiano a cura di G. Sannio Fancello e C. Cianchetti; Giunti O.S.: Firenze, Italy, 2008.

47. Wechsler, D. Wechsler Intelligence Scale for Children-Fourth Edition (WISC-IV); The Psychological Corporation: San Antonio, TX, USA, 2003.

48. Roid, G.H.; Miller, L.J. The Leiter International Performance Scale-Revised Edition; Psychological Assessment Resources: Lutz, FL, USA, 1997.

49. Lord, C.; Rutter, M.; DiLavore, P.C.; Risi, S.; Gotham, K.; Bishop, S. ADOS-2 Autism Diagnostic Observation Schedule, 2nd ed.; Western Psychological Services: Torrance, CA, USA, 2012.

50. Gotham, K.; Pickles, A.; Lord, C. Standardizing ADOS scores for a measure of severity in autism spectrum disorders. J. Autism Dev. Disord. 2009, 39, 693-705. [CrossRef]

51. Esler, A.N.; Bal, V.H.; Guthrie, W.; Wetherby, A.; Weismer, S.E.; Lord, C. The Autism Diagnostic Observation Schedule, Toddler Module: Standardized Severity Scores. J. Autism Dev. Disord. 2015, 45, 2704-2720. [CrossRef] [PubMed]

52. Database of Genomic Variants (DGV). Available online: http://dgv.tcag.ca/dgv/app/home (accessed on 26 July 2020).

53. Kearney, H.M.; Thorland, E.C.; Brown, K.K.; Quintero-Rivera, F.; South, S.T.; Working Group of the American College of Medical Genetics Laboratory Quality Assurance Committee. American College of Medical Genetics standards and guidelines for interpretation and reporting of postnatal constitutional copy number variants. Genet. Med. 2011, 13, 680-685. [CrossRef] [PubMed]

54. Online Mendelian Inheritance in Man (OMIM) Database. Available online: https://www.omim.org (accessed on 26 July 2020).

55. Simons Foundation Autism Research Initiative (SFARI). Gene Database. Available online: https://gene.sfari. org/database/human-gene (accessed on 26 July 2020).

56. Autism KnowledgeBase Version 2.0 (Autism KB 2.0). Database. Available online: http://db.cbi.pku.edu.cn/ autismkb_v2/index.php (accessed on 26 July 2020).

57. Krämer, A.; Green, J.; Pollard, J.; Tugendreich, S. Causal analysis approaches in Ingenuity Pathway Analysis. Bioinformatics 2014, 30, 523-530. [CrossRef] [PubMed]

58. ToppGene Suite. Available online: https://toppgene.cchmc.org (accessed on 31 August 2020).

59. Lal, D.; Pernhorst, K.; Klein, K.M.; Reif, P.; Tozzi, R.; Toliat, M.R.; Winterer, G.; Neubauer, B.; Nürnberg, P.; Rosenow, F.; et al. Extending the phenotypic spectrum of RBFOX1 deletions: Sporadic focal epilepsy. Epilepsia 2015, 56, e129-e133. [CrossRef] [PubMed]

60. Ciaccio, C.; Tucci, A.; Scuvera, G.; Estienne, M.; Esposito, S.; Milani, D. 16p13 microduplication without CREBBP involvement: Moving toward a phenotype delineation. Eur. J. Med. Genet. 2017, 60, 159-162. [CrossRef] [PubMed]

61. Gai, X.; Xie, H.M.; Perin, J.C.; Takahashi, N.; Murphy, K.; Wenocur, A.S.; D’Arcy, M.; O’Hara, R.J.; Goldmuntz, E.; Grice, D.E.; et al. Rare structural variation of synapse and neurotransmission genes in autism. Mol. Psychiatry 2012, 17, 402-411. [CrossRef] [PubMed]

62. Drinjakovic, J.; Jung, H.; Campbell, D.S.; Strochlic, L.; Dwivedy, A.; Holt, C.E. E3 ligase Nedd4 promotes axon branching by downregulating PTEN. Neuron 2010, 65, 341-357. [CrossRef] [PubMed]

63. Ishizuka, K.; Kimura, H.; Wang, C.; Xing, J.; Kushima, I.; Arioka, Y.; Oya-Ito, T.; Uno, Y.; Okada, T.; Mori, D.; et al. Investigation of Rare Single-Nucleotide PCDH15 Variants in Schizophrenia and Autism Spectrum Disorders. PLoS ONE 2016, 11, e0153224. [CrossRef] [PubMed]

64. Stone, J.L.; Merriman, B.; Cantor, R.M.; Geschwind, D.H.; Nelson, S.F. High density SNP association study of a major autism linkage region on chromosome 17. Hum. Mol. Genet. 2007, 16, 704-715. [CrossRef] [PubMed] 
65. Yang, Y.; Pan, C. Role of metabotropic glutamate receptor 7 in autism spectrum disorders: A pilot study. Life Sci. 2013, 92, 149-153. [CrossRef] [PubMed]

66. Baldan, F.; Gnan, C.; Franzoni, A.; Ferino, L.; Allegri, L.; Passon, N.; Damante, G. Genomic Deletion Involving the IMMP2L Gene in Two Cases of Autism Spectrum Disorder. Cytogenet. Genome Res. 2018, 154, 196-200. [CrossRef]

67. Ben Khelifa, H.; Soyah, N.; Ben-Abdallah-Bouhjar, I.; Gritly, R.; Sanlaville, D.; Elghezal, H.; Saad, A.; Mougou-Zerelli, S. Xp22.3 interstitial deletion: A recognizable chromosomal abnormality encompassing VCX3A and STS genes in a patient with X-linked ichthyosis and mental retardation. Gene 2013, 527, 578-583. [CrossRef]

68. Van Rijn, S.; Stockmann, L.; Borghgraef, M.; Bruining, H.; van Ravenswaaij-Arts, C.; Govaerts, L.; Hansson, K.; Swaab, H. The social behavioral phenotype in boys and girls with an extra X chromosome (Klinefelter syndrome and Trisomy X): A comparison with autism spectrum disorder. J. Autism Dev. Disord. 2014, 44, 310-320. [CrossRef]

69. Taylor, P.J.; Betts, G.A.; Maroulis, S.; Gilissen, C.; Pedersen, R.L.; Mowat, D.R.; Johnston, H.M.; Buckley, M.F. Dystrophin gene mutation location and the risk of cognitive impairment in Duchenne muscular dystrophy. PLoS ONE 2010, 5, e8803. [CrossRef]

70. Guo, H.; Peng, Y.; Hu, Z.; Li, Y.; Xun, G.; Ou, J.; Sun, L.; Xiong, Z.; Liu, Y.; Wang, T.; et al. Genome-wide copy number variation analysis in a Chinese autism spectrum disorder cohort. Sci. Rep. 2017, 7, 44155. [CrossRef]

71. Dabell, M.P.; Rosenfeld, J.A.; Bader, P.; Escobar, L.F.; El-Khechen, D.; Vallee, S.E.; Dinulos, M.B.P.; Curry, C.; Fisher, J.; Tervo, R.; et al. Investigation of NRXN1 deletions: Clinical and molecular characterization. Am. J. Med. Genet. Part A 2013, 161A, 717-731. [CrossRef]

72. Tropeano, M.; Howley, D.; Gazzellone, M.J.; Wilson, C.E.; Ahn, J.W.; Stavropoulos, D.J.; Murphy, C.M.; Eis, P.S.; Hatchwell, E.; Dobson, R.J.B.; et al. Microduplications at the pseudoautosomal SHOX locus in autism spectrum disorders and related neurodevelopmental conditions. J. Med. Genet. 2016, 53, 536-547. [CrossRef]

73. Srivastava, S.; Love-Nichols, J.A.; Dies, K.A.; Ledbetter, D.H.; Martin, C.L.; Chung, W.K.; Firth, H.V.; Frazier, T.; Hansen, R.L.; Prock, L.; et al. Meta-analysis and multidisciplinary consensus statement: Exome sequencing is a first-tier clinical diagnostic test for individuals with neurodevelopmental disorders. Genet. Med. 2019, 21, 2413-2421. [CrossRef] [PubMed]

74. Schaefer, G.B.; Mendelsohn, N.J. Professional Practice and Guidelines Committee Clinical genetics evaluation in identifying the etiology of autism spectrum disorders: 2013 guideline revisions. Genet. Med. 2013, 15, 399-407. [CrossRef] [PubMed]

75. Pinto, D.; Delaby, E.; Merico, D.; Barbosa, M.; Merikangas, A.; Klei, L.; Thiruvahindrapuram, B.; Xu, X.; Ziman, R.; Wang, Z.; et al. Convergence of genes and cellular pathways dysregulated in autism spectrum disorders. Am. J. Hum. Genet. 2014, 94, 677-694. [CrossRef] [PubMed]

76. Devlin, B.; Scherer, S.W. Genetic architecture in autism spectrum disorder. Curr. Opin. Genet. Dev. 2012, 22, 229-237. [CrossRef]

77. Chen, C.-H.; Chen, H.-I.; Chien, W.-H.; Li, L.-H.; Wu, Y.-Y.; Chiu, Y.-N.; Tsai, W.-C.; Gau, S.S.-F. High resolution analysis of rare copy number variants in patients with autism spectrum disorder from Taiwan. Sci. Rep. 2017, 7, 11919. [CrossRef]

78. Napoli, E.; Russo, S.; Casula, L.; Alesi, V.; Amendola, F.A.; Angioni, A.; Novelli, A.; Valeri, G.; Menghini, D.; Vicari, S. Array-CGH Analysis in a Cohort of Phenotypically Well-Characterized Individuals with "Essential" Autism Spectrum Disorders. J. Autism Dev. Disord. 2018, 48, 442-449. [CrossRef]

79. Barone, R.; Gulisano, M.; Amore, R.; Domini, C.; Milana, M.C.; Giglio, S.; Madia, F.; Mattina, T.; Casabona, A.; Fichera, M.; et al. Clinical correlates in children with autism spectrum disorder and CNVs: Systematic investigation in a clinical setting. Int. J. Dev. Neurosci. 2020, 80, 276-286. [CrossRef]

80. Bacchelli, E.; Cameli, C.; Viggiano, M.; Igliozzi, R.; Mancini, A.; Tancredi, R.; Battaglia, A.; Maestrini, E. An integrated analysis of rare CNV and exome variation in Autism Spectrum Disorder using the Infinium PsychArray. Sci. Rep. 2020, 10, 3198. [CrossRef]

81. Jacquemont, S.; Coe, B.P.; Hersch, M.; Duyzend, M.H.; Krumm, N.; Bergmann, S.; Beckmann, J.S.; Rosenfeld, J.A.; Eichler, E.E. A higher mutational burden in females supports a "female protective model" in neurodevelopmental disorders. Am. J. Hum. Genet. 2014, 94, 415-425. [CrossRef] 
82. Girirajan, S.; Rosenfeld, J.A.; Coe, B.P.; Parikh, S.; Friedman, N.; Goldstein, A.; Filipink, R.A.; McConnell, J.S.; Angle, B.; Meschino, W.S.; et al. Phenotypic heterogeneity of genomic disorders and rare copy-number variants. N. Engl. J. Med. 2012, 367, 1321-1331. [CrossRef]

83. Newman, S.; Hermetz, K.E.; Weckselblatt, B.; Rudd, M.K. Next-generation sequencing of duplication CNVs reveals that most are tandem and some create fusion genes at breakpoints. Am. J. Hum. Genet. 2015, 96, 208-220. [CrossRef] [PubMed]

84. Rubenstein, E.; Wiggins, L.D.; Lee, L.-C. A Review of the Differences in Developmental, Psychiatric, and Medical Endophenotypes Between Males and Females with Autism Spectrum Disorder. J. Dev. Phys. Disabil. 2015, 27, 119-139. [CrossRef] [PubMed]

85. Charman, T.; Loth, E.; Tillmann, J.; Crawley, D.; Wooldridge, C.; Goyard, D.; Ahmad, J.; Auyeung, B.; Ambrosino, S.; Banaschewski, T.; et al. The EU-AIMS Longitudinal European Autism Project (LEAP): Clinical characterisation. Mol. Autism 2017, 8, 27. [CrossRef] [PubMed]

86. Knutsen, J.; Crossman, M.; Perrin, J.; Shui, A.; Kuhlthau, K. Sex differences in restricted repetitive behaviors and interests in children with autism spectrum disorder: An Autism Treatment Network study. Autism 2019, 23, 858-868. [CrossRef]

87. Warrier, V.; Toro, R.; Won, H.; Leblond, C.S.; Cliquet, F.; Delorme, R.; De Witte, W.; Bralten, J.; Chakrabarti, B.; Børglum, A.D.; et al. Social and non-social autism symptoms and trait domains are genetically dissociable. Commun. Biol. 2019, 2, 328. [CrossRef]

88. Uljarević, M.; Evans, D.W.; Alvares, G.A.; Whitehouse, A.J.O. Short report: Relationship between restricted and repetitive behaviours in children with autism spectrum disorder and their parents. Mol. Autism 2016, 7, 29. [CrossRef]

89. Szatmari, P.; Liu, X.-Q.; Goldberg, J.; Zwaigenbaum, L.; Paterson, A.D.; Woodbury-Smith, M.; Georgiades, S.; Duku, E.; Thompson, A. Sex differences in repetitive stereotyped behaviors in autism: Implications for genetic liability. Am. J. Med. Genet. Part B Neuropsychiatr. Genet. 2012, 159B, 5-12. [CrossRef]

90. Mazina, V.; Gerdts, J.; Trinh, S.; Ankenman, K.; Ward, T.; Dennis, M.Y.; Girirajan, S.; Eichler, E.E.; Bernier, R. Epigenetics of autism-related impairment: Copy number variation and maternal infection. J. Dev. Behav. Pediatr. 2015, 36, 61-67. [CrossRef]

91. Niarchou, M.; Chawner, S.J.R.A.; Doherty, J.L.; Maillard, A.M.; Jacquemont, S.; Chung, W.K.; Green-Snyder, L.; Bernier, R.A.; Goin-Kochel, R.P.; Hanson, E.; et al. Psychiatric disorders in children with 16p11.2 deletion and duplication. Transl. Psychiatry 2019, 9, 8. [CrossRef]

92. Bishop, D.V.M.; Jacobs, P.A.; Lachlan, K.; Wellesley, D.; Barnicoat, A.; Boyd, P.A.; Fryer, A.; Middlemiss, P.; Smithson, S.; Metcalfe, K.; et al. Autism, language and communication in children with sex chromosome trisomies. Arch. Dis. Child. 2011, 96, 954-959. [CrossRef]

93. Fountain, M.D.; Oleson, D.S.; Rech, M.E.; Segebrecht, L.; Hunter, J.V.; McCarthy, J.M.; Lupo, P.J.; Holtgrewe, M.; Moran, R.; Rosenfeld, J.A.; et al. Pathogenic variants in USP7 cause a neurodevelopmental disorder with speech delays, altered behavior, and neurologic anomalies. Genet. Med. 2019, 21, 1797-1807. [CrossRef] [PubMed]

94. Moyses-Oliveira, M.; Yadav, R.; Erdin, S.; Talkowski, M.E. New gene discoveries highlight functional convergence in autism and related neurodevelopmental disorders. Curr. Opin. Genet. Dev. 2020, 65, 195-206. [CrossRef] [PubMed]

95. Cheroni, C.; Caporale, N.; Testa, G. Autism spectrum disorder at the crossroad between genes and environment: Contributions, convergences, and interactions in ASD developmental pathophysiology. Mol. Autism. 2020, 11, 69. [CrossRef] [PubMed]

96. Bourgeron, T. From the genetic architecture to synaptic plasticity in autism spectrum disorder. Nat. Rev. Neurosci. 2015, 16, 551-563. [CrossRef]

(C) 2020 by the authors. Licensee MDPI, Basel, Switzerland. This article is an open access article distributed under the terms and conditions of the Creative Commons Attribution (CC BY) license (http://creativecommons.org/licenses/by/4.0/). 